\title{
20. PETROLOGY AND K-Ar AGE OF VOLCANIC TUFF AND ASH FROM THE WALVIS SEAMOUNT PROVINCE, DSDP SITE 359, LEG 39
}

\author{
R.V. Fodor, K. Keil, and J.W. Husler, Department of Geology and Institute \\ of Meteoritics, University of New Mexico, Albuquerque, New Mexico \\ and \\ E.H. McKee, U.S. Geological Survey, Menlo Park, California
}

\begin{abstract}
An ash-flow tuff of 3.3 meters thickness cored from a seamount at the southwest extremity of the Walvis Ridge $(\sim 1000 \mathrm{~km}$ east of the Mid-Atlantic Ridge) has trachytic bulk composition $\left(\mathrm{SiO}_{2} 62.5 \mathrm{wt}\right.$ $\%$; total alkalis $12 \mathrm{wt} \%$ ) and contains abundant alkali feldspar (avg. $\mathrm{An}_{4} \mathrm{Ab}_{57} \mathrm{Or}_{39}$ ), clinopyroxene ( $\mathrm{Fs}_{18} \mathrm{En}_{37} \mathrm{~W}_{04}$ ), biotite, and $\mathrm{Fe}-\mathrm{Ti}$ oxides in a dusty, partly devitrified matrix. Moderately compacted pumice lapilli are abundant, but no original shard structures remain. The relative freshness and absence of graded bedding and marine material indicate that the tuff was emplaced subaerially. Fossils in overlying sediments indicate an open-marine environment about $40 \mathrm{~m} . \mathrm{y}$. in age. Within those sediments are three ash layers, $3.6,4.0$, and 4.6 meters above the tuff. The ash is composed of high$\mathrm{SiO}_{2}$ glass $(\sim 69$ wt $\%)$ and contains alkali feldspar, hedenbergite, and $\mathrm{Fe}-\mathrm{Ti}$ oxides. The feldspar in the trachytic ash flow gives a $\mathrm{K}-\mathrm{Ar}$ age of $40.1 \pm 1$ m.y..

The ash-flow tuff is compositionally similar to trachytes on the nearby islands of Tristan da Cunha and Gough (moderately alkalic volcanic provinces). The seamount it caps probably represents a volcanic center that originated on or near the Mid-Atlantic Ridge at least $50 \mathrm{~m} . \mathrm{y}$. ago (based on spreading rates averaging $2 \mathrm{~cm} / \mathrm{yr}$ and its location between magnetic anomalies 21 and 31 ), differentiated from basalt to trachyte, and migrated northeastward. Overlying open-marine sediments about the same age as the tuff indicate that the tuff was submerged shortly after its emplacement; this probably happened by collapse of a summit caldera. The ash layers in overlying sediments indicate that intermediate to silicic volcanism persisted in the region of the seamount until at least late Eocene.
\end{abstract}

\section{INTRODUCTION}

Coring at the southwest extremity of the Walvis Ridge (eastern South Atlantic; Site 359) (Figure 1) yielded volcanic material that provides new data on the composition of the Walvis seamount province. Material recovered includes 3.3 meters of ash-flow tuff and three volcanic-ash layers within overlying sediments. This report presents the results and interpretations of chemical, mineralogical, and petrological studies of the ash-flow tuff and the volcanic ash, and the K-Ar age of the ash flow.

\section{ANALYTICAL PROCEDURES}

Whole-rock and mineral analyses were made according to procedures described by Fodor et al. (this volume). The age of the ash flow was determined from alkali feldspar separated from the sample. Less than 0.5 $\mathrm{g}$ of the feldspar was recovered after crushing, heavy liquid and magnetic separation, and cleaning procedures. Splits of this sample were used for $\mathrm{K}_{2} \mathrm{O}$ and
Ar analyses. Argon analyses were carried out using standard isotope-dilution techniques. Mass analysis was with a Nier-type 60 inch radius $60^{\circ}$ sector mass spectrometer operated in the static mode. The potassium analyses were made by flame photometry using a lithium internal standard. The decay constants used for $\mathrm{K}^{40}$ are $\lambda \mathrm{e}=0.585 \times 10^{-10} \mathrm{yr}^{-1}$ and $\lambda \beta=4.72 \times$ $10^{-10} \mathrm{yr}^{-1}$, and the atomic abundance of $\mathrm{K}^{40}$ is $1.19 \times$ $10^{-4} \mathrm{~mole} / \mathrm{mole}$.

\section{GENERAL DESCRIPTIONS AND PETROGRAPHY}

Site 359 (Figure 1) is located about $500 \mathrm{~km}$ northeast of the volcanic islands of Tristan da Cunha and Gough, about $1000 \mathrm{~km}$ from the Mid-Atlantic Ridge (MAR), and between magnetic anomalies 21 and 31 (Pitman et al., 1975). A seismic profile (Figure 2) of Site 359 clearly shows it to be a seamount-one of nearly 40 seamounts and guyots that form the Walvis seamount (guyot) province located at the southwestern edge of the Walvis Ridge. This seamount group, in turn, is considered to be one of three major segments forming the Walvis Ridge province (Connary, 1972). 


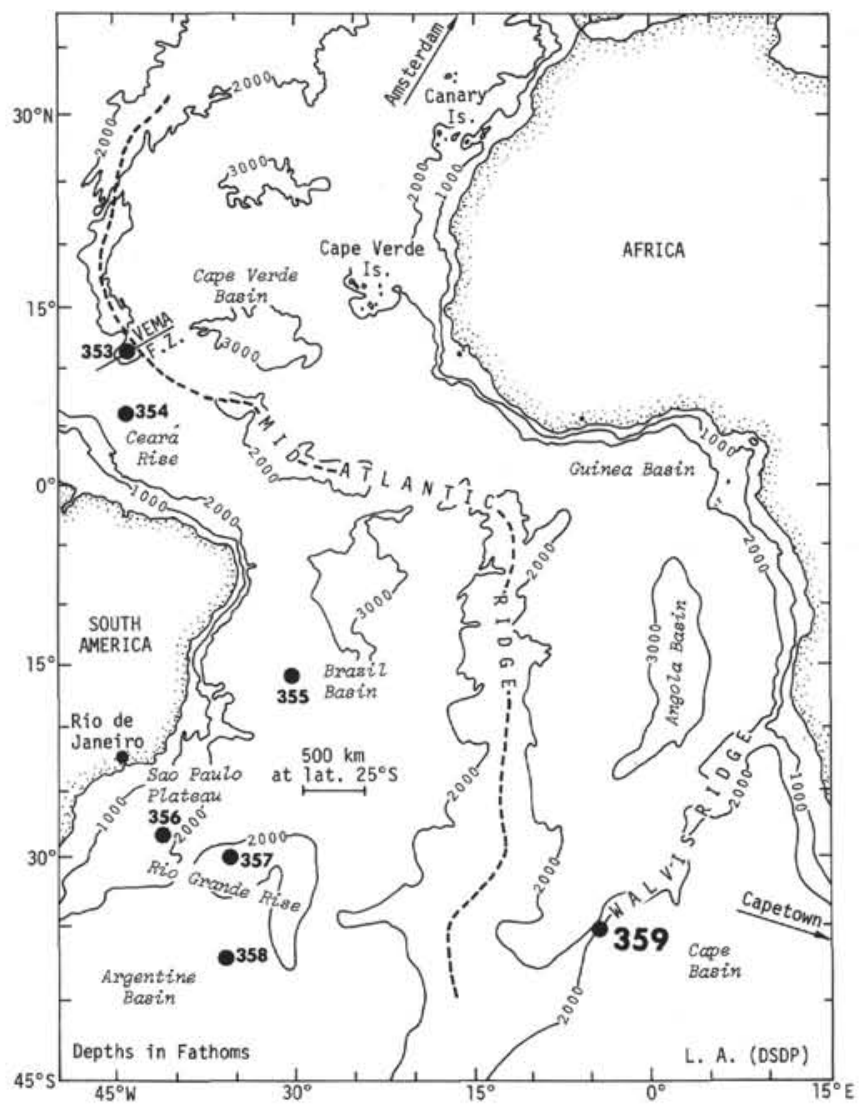

Figure 1. Map of the South Atlantic Ocean showing the location of Site 359 and other sites drilled during Leg $39 \mathrm{~b}$.

The ash-flow tuff was cored from the top of the seamount about 90 meters below the sea floor in a water depth of about 1658 meters. It was not completely penetrated and underlying material remains unknown. Lying directly above the tuff are openmarine sediments containing fauna about $40 \mathrm{~m}$.y. in age (Boersma, this volume).

The Walvis ash-flow is medium gray and contains abundant feldspar crystals (up to $5 \mathrm{~mm}$ long), minor amounts of green pyroxene crystals and biotite, and medium light gray pumice fragments (up to $1 \mathrm{~cm}$ ) in a fine-grained matrix (Figure 3). It is moderately indurated, although crumbles slightly when rubbed. Moderately-compacted pumice lapilli indicate at least mild welding of the ash flow. In hand specimen, the tuff appears free of alteration and weathering.

Lying about $3.6,4.0$, and $4.6 \mathrm{~m}$ above the tuff in sandy, clayey, partly volcanic sediments are three greenish to greenish-gray ash layers. Each layer is about $1 \mathrm{~cm}$ thick and consists of pumice ranging in size from fine ash $(<0.25 \mathrm{~mm})$ to ash $4 \mathrm{~mm}$ in size.

Thin-section examination of the Walvis tuff shows the feldspar mainly as rectangular crystals averaging 0.5 to $1 \mathrm{~mm}$ in size, having distinct cleavage and Carlsbad twinning $\left(2 V x=15-20^{\circ}\right.$; dispersion $\left.r>v\right)$, and being free of alteration (Figure 4). Rare, green clinopyroxene grains also appear fresh, whereas biotite is highly oxidized. Oxides are present as small ( $\sim 1$ to 5 $\mu \mathrm{m})$ grains.

Pumice lapilli are abundant and compaction ratios vary from about $1: 1$ to about $10: 1$, indicating moderate welding (Figures 3, 4,6). Cellular and fibrous structures in the pumice are no longer visible, probably because of the effects of seawater and devitrification; some spherulitic texture has developed in the pumice. The pumice contains abundant crystallites of feldspar, some parallel-aligned, and there is preferred horizontal orientation of the pumice fragments and feldspar crystals, apparently due to flowage followed by compaction. The tuff groundmass is dusty and glass shards are not visible.

The ash particles in the ash layers above the tuff are tubular, or cellular, and their long axes are generally parallel to the thin, pipe-shaped vesicles (Figure 7). Crystals of feldspar, pyroxene, and oxides are included in the ash particles and are associated as individual grains in the ash layers.

\section{ANALYTICAL RESULTS}

\section{Chemistry}

Whole-rock compositions (Table 1) of the ash-flow tuff sampled at three intervals in the 3.3 meter core show that it is homogeneous throughout. The only variation present is somewhat higher $\mathrm{Al}_{2} \mathrm{O}_{3}$ and lower $\mathrm{FeO}$ contents in the middle sample, and this could be due to slightly more modal feldspar in that sample. The $\mathrm{SiO}_{2}(62.5 \mathrm{wt} \%)$ and total alkali (12 wt \%) contents, and the low $\mathrm{Na}_{2} \mathrm{O} / \mathrm{K}_{2} \mathrm{O}$ ratios $(0.88)$ indicate that the tuff is an intermediate differentiate and is best classified as a trachyte. Bulk compositions compare well with those of other intermediate alkali-rich rocks of the South Atlantic Ocean, such as trachytes of the nearby islands of the Tristan da Cunha group and Gough (Table 1). With respect to $\mathrm{Na}_{2} \mathrm{O}$ and $\mathrm{K}_{2} \mathrm{O}$ contents, the seamount trachyte fits within the range of trachyte on those islands (Baker et al., 1964; Le Maitre, 1962); the Gough trachytes, however, are richer in $\mathrm{FeO}$ content (Table 1; Le Maitre, 1962). Compared to differentiated rocks of other oceanic island provinces, such as the rhyodacite of Hawaii (Bauer et al., 1973), or the trachyte of Easter Island (Baker et al., 1974), the Walvis tuff is far richer in total alkali content (Table 1). On the other hand, it is similar to trachytes of Hawaii, except for higher $\mathrm{Na}_{2} \mathrm{O} / \mathrm{K}_{2} \mathrm{O}$ ratios in the Hawaiian samples (Table 1).

Normative mineralogy has quartz and hematite (Table 1). When $\mathrm{Fe}_{2} \mathrm{O}_{3} / \mathrm{FeO}$ is recalculated to 0.1 , a more realistic initial ratio, the norm no longer contains $\mathrm{hm}$ but still contains a small amount of $q$. Like many other oceanic trachytes, the composition of the Walvis tuff borders on $\mathrm{SiO}_{2}$-oversaturation.

The elements $\mathrm{Co}, \mathrm{Cr}, \mathrm{Ni}$, and $\mathrm{V}$ (Table 1) are low in concentration, as expected for an intermediate volcanic rock. The $\mathrm{Rb}$ and $\mathrm{Ba}$ contents are also low, particularly when considering the high bulk-rock $\mathrm{K}_{2} \mathrm{O}$ content. Trachytes on other islands (Table 1) contain $\mathrm{Rb}$ and $\mathrm{Ba}$ in amounts expected for K-rich rocks (e.g., compare the $\mathrm{K} / \mathrm{Rb}$ ratios of the seamount trachyte to those of Tristan and Easter Island; Table 1).

\section{Mineralogy}

Compositions of feldspar in the Walvis tuff are at the border between anorthoclase and sanidine, averaging about $\mathrm{An}_{4} \mathrm{Ab}_{57} \mathrm{Or}_{39}$ (Table 2). Much of the compositional variation is related to grain size, where 


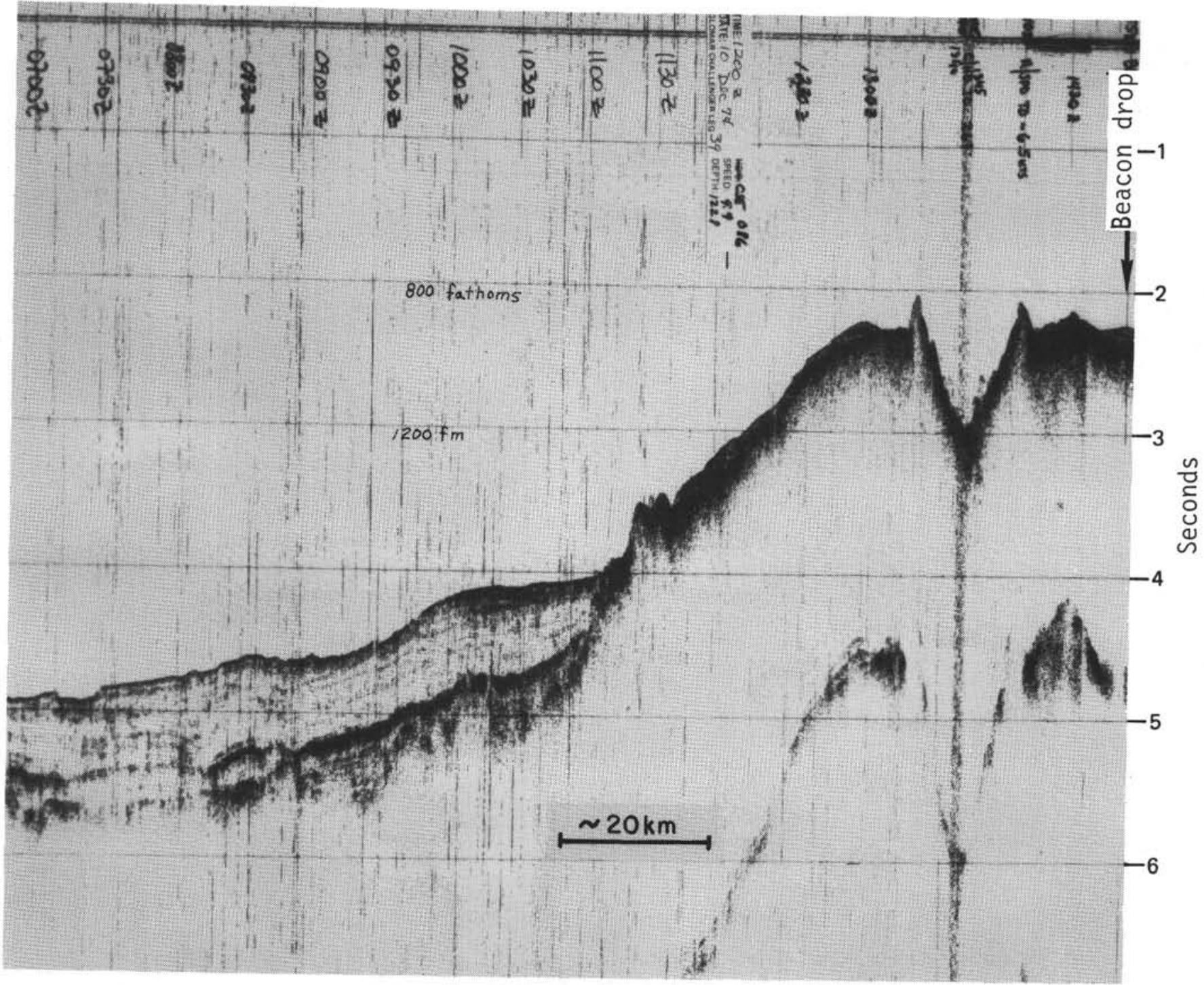

Figure 2. Shipboard seismic profile of Site 359 illustrating that it is a seamount about 900 fathoms below sea level. The righthand side of the profile is a mirror image due to retracing of the ship's original path. Drilling was done on the summit (beneath "beacon drop").

$\mathrm{K}_{2} \mathrm{O}$ content increases with decreasing grain size from phenocrysts, to groundmass laths, to microlites (Figure 8 , Table 2). Similarly, there is zoning in the phenocrysts with cores richer in $\mathrm{K}_{2} \mathrm{O}$ content than the rims. This $\mathrm{K}$ $\mathrm{Na}$ fractionation is in accordance with the crystallization scheme of alkali feldspar as shown experimentally by Tuttle and Bowen (1958). A check for $\mathrm{Ba}$ in the feldspar showed that it is below the detection limit of the electron microprobe.

Clinopyroxene in the tuff (Table 3) is higher in $\mathrm{FeO}$ content (Fs18) relative to basaltic clinopyroxenes, but is not as high in $\mathrm{FeO}$ and $\mathrm{Na}_{2} \mathrm{O}$ contents as clinopyroxene in some trachytes of Gough (Le Maitre, 1962) and Hawaii (Fodor et al., 1975). Also, it is relatively low in $\mathrm{TiO}_{2}$ and $\mathrm{Al}_{2} \mathrm{O}_{3}$ contents unlike pyroxene in the Gough trachytes (Le Maitre, 1962) but similar to pyroxenes in Hawaii trachyte (Fodor et al., 1975). A small amount of $\mathrm{K}_{2} \mathrm{O}$ was also detected in the clinopyroxene. Biotite (Table 3) has high $\mathrm{TiO}_{2}$ content (6.9 wt \%), but otherwise is much like biotite analyzed from many other dif- ferentiated volcanic rocks (e.g., Carmichael, 1967). The biotite $\mathrm{Fe} / \mathrm{Mg}$ ratio, however, is far higher than that of biotite in the most highly differentiated rock (rhyodacite) of Hawaii (Bauer et al., 1973).

Oxides in the tuff include magnetite, slightly titaniferous, and ilmenite (Table 4). The low ulvöspinel and $\mathrm{MgO}$ and the high $\mathrm{MnO}$ contents of the magnetite relative to those values in titaniferous magnetite of basaltic rocks (e.g., Fodor et al., this volume) is compatible with crystallization from a differentiated magma. In contrast, the only evidence of ilmenite having crystallized in a differentiate is the relatively high $\mathrm{MnO}$ content $(2.2 \mathrm{wt} \%)$. The magnetite is highly variable with respect to $\mathrm{FeO}$ and $\mathrm{TiO}_{2}$ contents, and grains having the highest $\mathrm{FeO}$ were observed mainly within pumice lapilli. Applying the average ulvöspinel content of 22.4 mole \% in the magnetite to experimental data of Buddington and Lindsley (1964) yields an equilibration temperature of about $700^{\circ} \mathrm{C}$ and an oxygen fugacity of $10^{-17}$ atmosphere. 


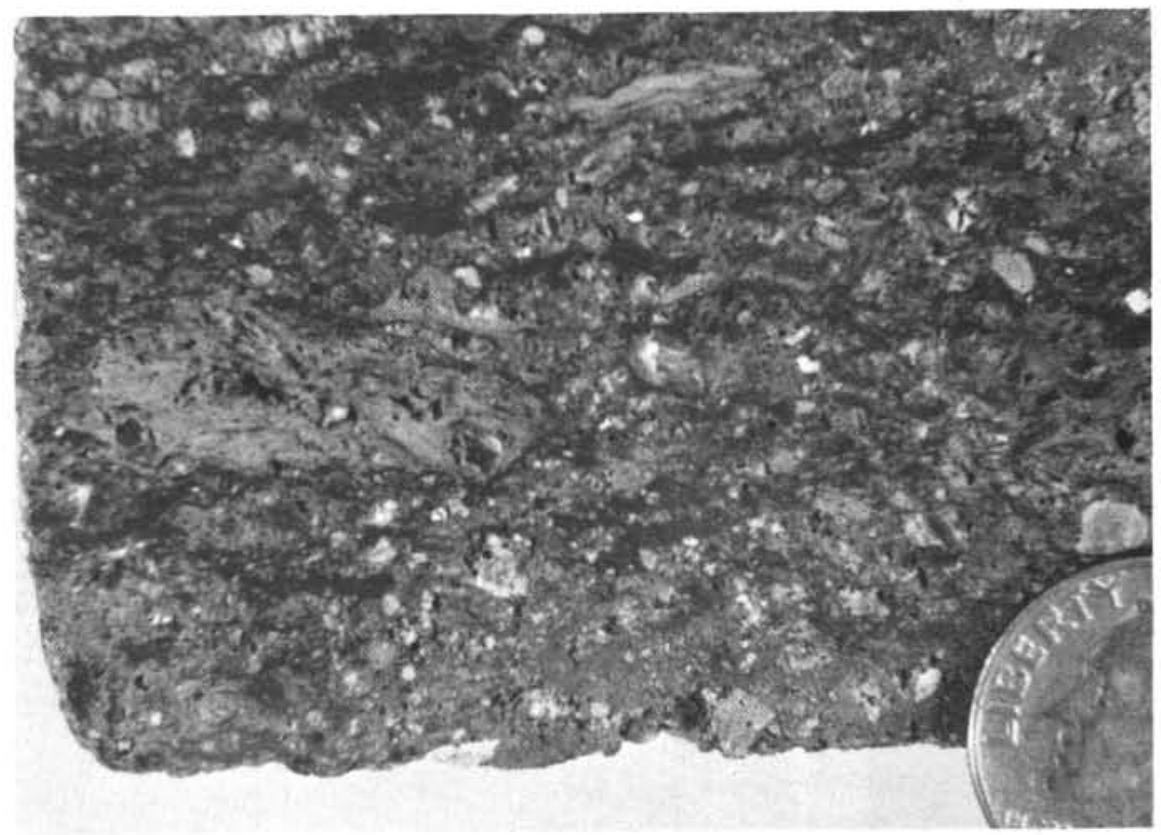

Figure 3. Macrophotograph of a core section of the Walvis trachytic ash-flow tuff showing pumice lapilli and some alkali feldspar phenocrysts. The coin provides scale.

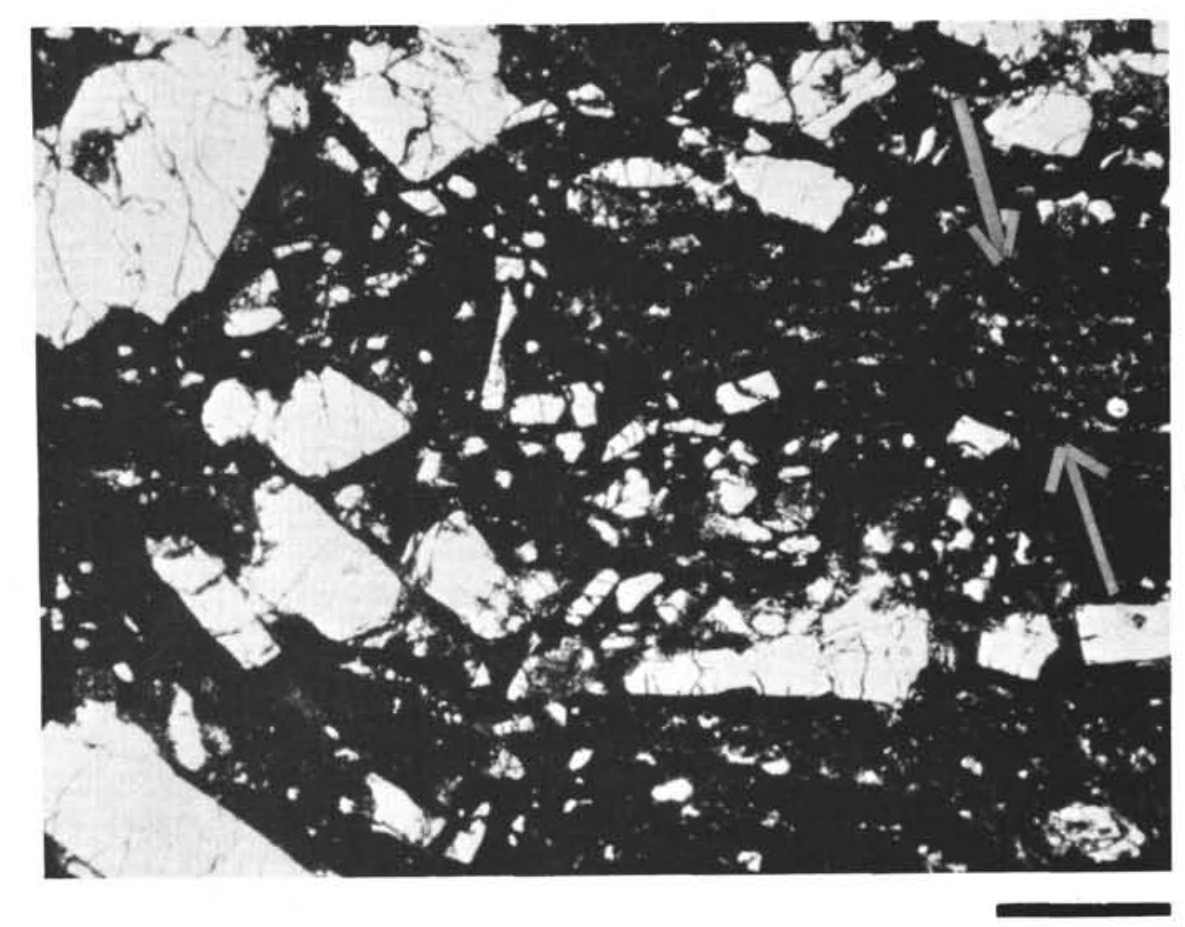

Figure 4. Alkali feldspar phenocrysts and moderately compacted pumice lapilli (between arrows) in the dark matrix of the Walvis trachytic ash-flow tuff. Feldspar composition is given in Table 2 and Figure 8. Plane polarized light; scale bar equals $1 \mathrm{~mm}$.

The matrix of the tuff approaches alkali feldspar in composition, indicating that much of the original glass is devitified. This is in agreement with textural observations.
Glass composing the three ash layers overlying the tuff are high in $\mathrm{SiO}_{2}$ content $(\sim 69$ wt \%) and have $\mathrm{Na}_{2} \mathrm{O} / \mathrm{K}_{2} \mathrm{O}$ ratios that are less than 1 and compatible with those for the tuff (Table 5). Also, the glass is rich 


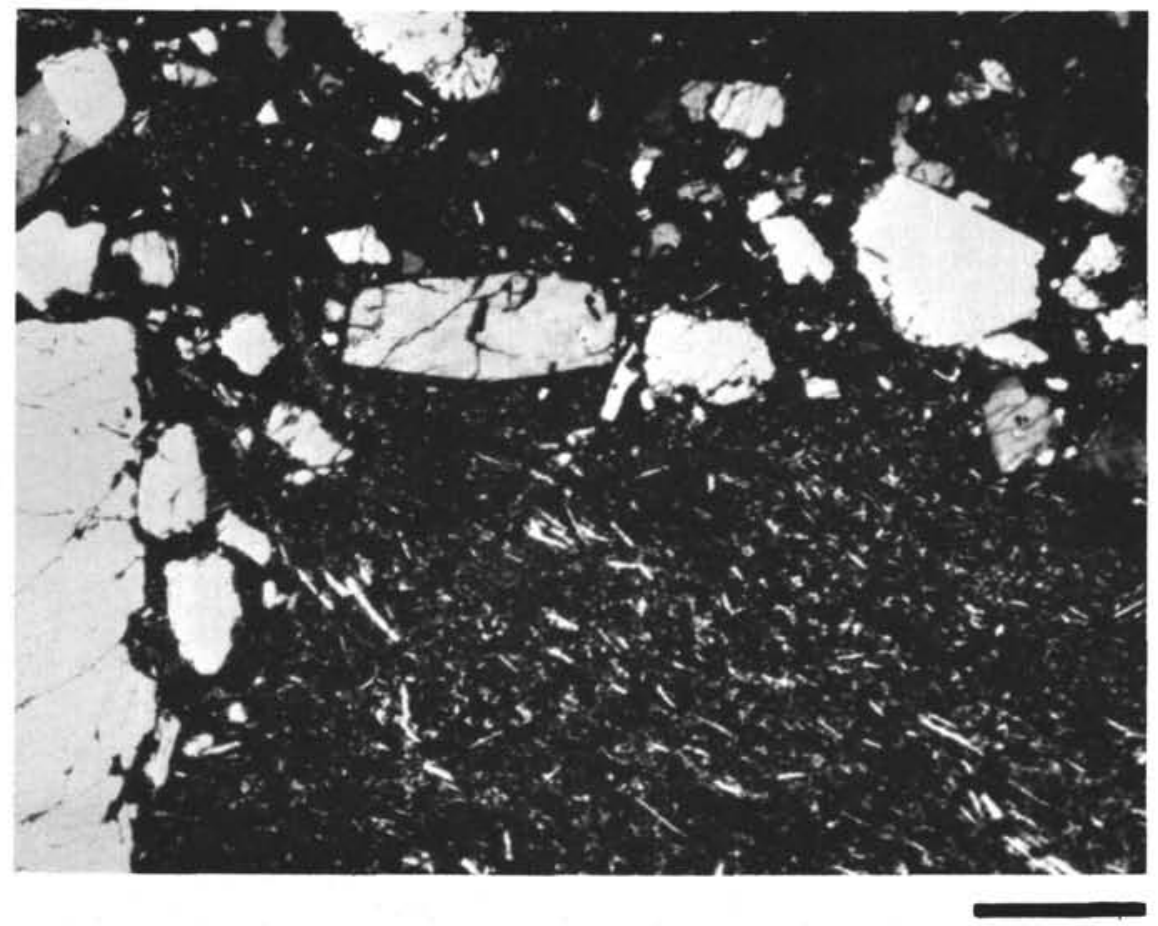

Figure 5. A large pumice fragment in the Walvis trachytic ash-flow tuff (lower right) containing crystallites of alkali feldspar. Feldspar composition given in Table 2 and Figure 8. Crossed nicols; scale bar equals $1 \mathrm{~mm}$.

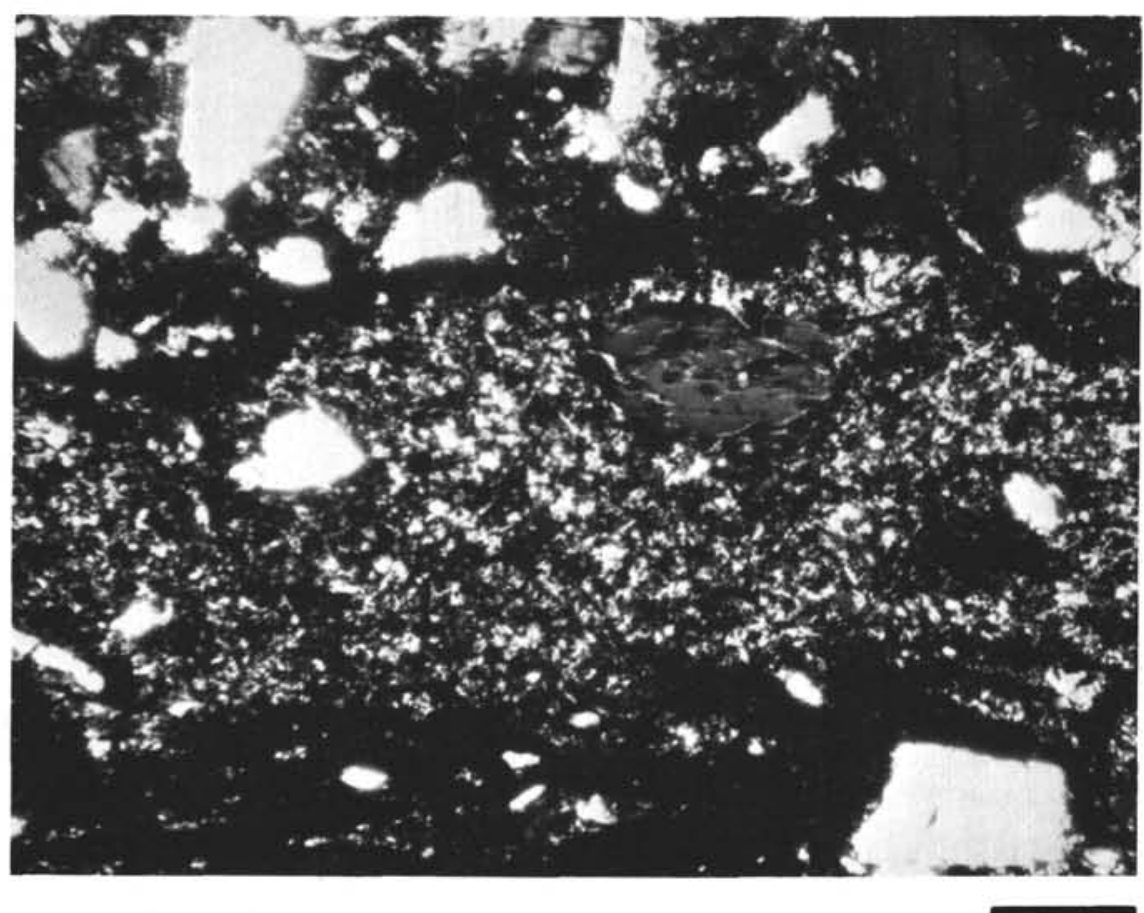

Figure 6. A highly crystalline, flattened, pumice lapilli in the Walvis trachytic ash-flow tuff containing a large clinopyroxene grain (dark). The light colored flakes in the pumice are alkali feldspar (see Table 2; Figure 8). Crossed nicols; scale bar equals $0.5 \mathrm{~mm}$.

in $\mathrm{FeO}$ content for material that is highly differentiated. If the glass composition is assumed to be an indicator for the bulk composition, it appears that between the time of deposition of the first $(3-4,67 \mathrm{~cm})$ and third ash 


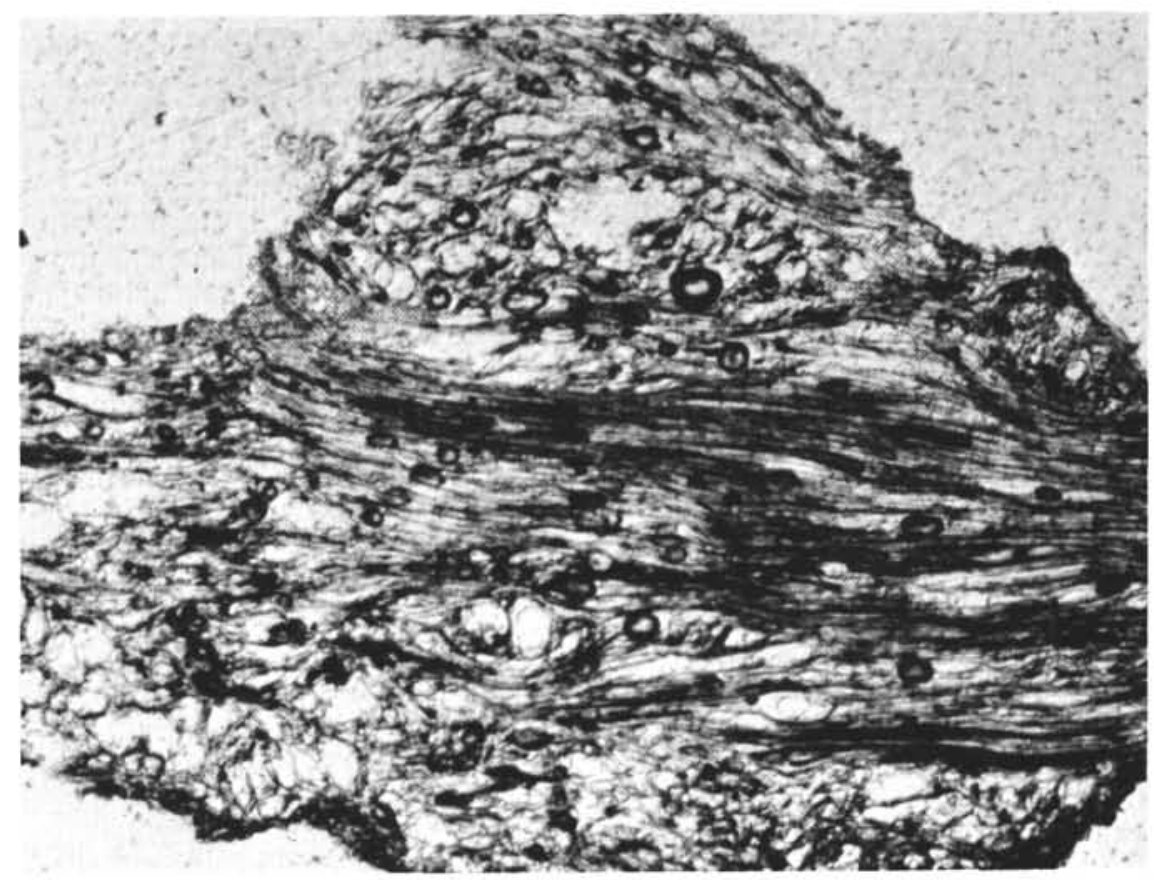

Figure 7. The tubular structure of ash (1 mm wide) from the ash layer 3-4-25. Glass composition is presented in Table 6. Plane polarized light.

layers $(3-3,120 \mathrm{~cm})$, represented by about 1 meter of sedimentation, there were no significant compositional changes in the volcanic source (or sources) for the ash, as indicated by their nearly identical glass compositions (Table 5). One small difference in glass compositions is decreasing $\mathrm{CaO}$ content with time, which is reflected in the compositions of the alkali feldspars associated with these ash deposits; Ca content in the feldspar decreases from 0.27 to $<0.01 \mathrm{wt} \%$ from oldest to youngest (Table 2). On the other hand, the feldspar is compositional between sanidine and anorthoclase, as it is in the Walvis ash-flow tuff (Table 2).

The pyroxene associated with the middle ash layer (3$4,25 \mathrm{~cm}$ ) is hedenbergite, greatly enriched in Fe relative to pyroxene in the tuff (Table 3 ). This high-Fe, low$\mathrm{MgO}$ pyroxene is compatible with the high $\mathrm{FeO}$ (3.8 wt $\%)$ and low $\mathrm{MgO}(<0.01 \mathrm{wt} \%)$ contents of the glass, and represents extreme clinopyroxene fractionation. It is substantially richer in $\mathrm{FeO}$ content than the pyroxene reported by Le Maitre (1962) for a Gough Island pyroxene (Fs40), but that pyroxene is enriched in $\mathrm{Na}$.

A titaniferous magnetite within a feldspar grain and an ilmenite grain in the ash were also analyzed (Table 4). The $\mathrm{TiO}_{2}$ content of the magnetite is substantially higher than $\mathrm{TiO}_{2}$ in the magnetite of the tuff (Table 4), and it more closely resembles $\mathrm{TiO}_{2}$ values in magnetite of more mafic (e.g., basaltic) material (e.g., Fodor et al., this volume). On the other hand, the high $\mathrm{MnO}$ and low $\mathrm{MgO}$ contents indicate that the magnetite is compatible with a differentiate. The presence of magnetite within feldspar indicates equilibration between the two oxides was unlikely, and therefore oxide geothermometry using coexisting magnetite and ilmenite is not meaningful here.

\section{Radiometric Age}

The age of the trachytic ash flow, determined on alkali feldspar separated from the sample, is $40.1 \pm 1$ m.y. Analytical values are $\mathrm{K}_{2} \mathrm{O}=7.38$ wt $\%$, which agrees well with the composition determined for the phenocrysts by electron microprobe (Table 2), radiogenic $\mathrm{Ar}^{40}=4.4870 \times 10^{-10} \mathrm{~mole} / \mathrm{g}$, and radiogenic $\mathrm{Ar}^{40} /$ total $\mathrm{Ar}^{40}=0.687$.

The precision of the date, shown as the \pm value, is the analytical uncertainty in the measurement of radiogenic argon 40 and potassium in the sample. The value is determined on the basis of experience with duplicate analyses in the Menlo Park laboratories.

\section{DISCUSSION}

The uppermost volcanic rock on the seamount at Site 359 (southwest Walvis Ridge) is compositionally similar to trachytes present on the nearby South Atlantic islands of Tristan da Cunha and Gough. Bulk chemical analyses showed no significant compositional changes throughout the 3.3-meter core, and microscope and microprobe examination showed that it is an ashflow tuff rich in alkali feldspar (anorthoclase-sanidine). This rock is far more differentiated in composition than the volcanic rocks dredged from the northeast extremity of the Walvis Ridge (Hekinian, 1972).

Although the Walvis trachyte, like other oceanic intermediate rocks, is probably a differentiate from a basaltic magma, the low $\mathrm{Rb}$ and $\mathrm{Ba}$ (Table 1) are unusual for such K-rich rocks. Possibly the trachyte is a derivative of a magma that was previously depleted in $\mathrm{Rb}$ and $\mathrm{Ba}$ by the fractionation of K-bearing phases in which $\mathrm{Rb}$ and $\mathrm{Ba}$ concentrate (e.g., Ridley, 1970). 
TABLE 1

Bulk Compositions and Molecular Norms of the Ash-Flow Tuff (Columns 1, 2, 3; top, middle, bottom of core, respectively) from the Walvis Seamount Province, Eastern South Atlantic Ocean, Compared to Trachytes from the Tristan da Cunha Group (Column 4, 5) Gough Island (Column 6), Rhyodacite of Hawaii (Column 7), Trachyte of Easter Island (Column 8), and Trachyte of Hawaii (Column 9).

\begin{tabular}{|c|c|c|c|c|c|c|c|c|c|}
\hline & $1^{\mathrm{a}}$ & $2^{a}$ & $3^{a}$ & 4 & 5 & 6 & 7 & 8 & 9 \\
\hline $\mathrm{SiO}_{2}$ & 62.63 & 62.21 & 62.39 & 62.50 & 62.23 & 62.45 & 66.14 & 66.36 & 61.89 \\
\hline $\mathrm{TiO}_{2}$ & 0.68 & 0.80 & 0.69 & 0.38 & 0.65 & 0.38 & 0.54 & 0.34 & 0.51 \\
\hline $\mathrm{Al}_{2} \mathrm{O}_{3}$ & 18.80 & 19.55 & 18.75 & 20.39 & 18.43 & 17.92 & 15.25 & 14.70 & 18.18 \\
\hline $\mathrm{Fe}_{2} \mathrm{O}_{3}$ & 2.22 & 1.67 & 2.67 & 0.31 & 1.68 & 2.06 & 1.38 & 3.68 & 3.84 \\
\hline $\mathrm{FeO}$ & 0.96 & 0.75 & 0.90 & 0.84 & 0.60 & 3.11 & 1.68 & 1.21 & 1.03 \\
\hline $\mathrm{MnO}$ & 0.07 & 0.04 & 0.07 & 0.09 & 0.12 & 0.16 & 0.06 & 0.12 & 0.23 \\
\hline $\mathrm{MgO}$ & 0.49 & 0.42 & 0.49 & 0.02 & 0.11 & 0.09 & 1.66 & 0.05 & 0.50 \\
\hline $\mathrm{CaO}$ & 0.75 & 0.93 & 0.90 & 1.28 & 1.16 & 1.17 & 2.82 & 1.75 & 1.33 \\
\hline $\mathrm{Na}_{2} \mathrm{O}$ & 5.63 & 5.70 & 5.63 & 5.93 & 6.77 & 6.47 & 4.47 & 6.34 & 7.26 \\
\hline $\mathrm{K}_{2} \mathrm{O}$ & 6.45 & 6.50 & 6.20 & 7.08 & 6.28 & 6.14 & 3.66 & 4.05 & 3.91 \\
\hline $\mathrm{H}_{2} \mathrm{O}^{-}$ & 0.57 & 0.46 & 0.58 & 0.69 & 0.06 & 0.16 & 0.10 & 0.52 & 0.64 \\
\hline $\mathrm{H}_{2} \mathrm{O}^{+}$ & 0.87 & 0.96 & 0.76 & 0.64 & 1.60 & 0.27 & 1.94 & 0.82 & 0.43 \\
\hline $\mathrm{P}_{2} \mathrm{O}_{5}$ & 0.13 & 0.15 & 0.12 & 0.10 & 0.32 & 0.09 & 0.18 & 0.02 & 0.15 \\
\hline $\mathrm{CO}_{2}$ & $<0.01$ & $<0.01$ & $<0.01$ & - & - & - & - & - & - \\
\hline Total & 100.25 & 100.14 & 100.15 & 100.25 & 100.01 & 100.47 & 99.88 & 99.96 & 99.90 \\
\hline $\mathrm{Na}_{2} \mathrm{O} / \mathrm{K}_{2} \mathrm{O}$ & 0.87 & 0.88 & 0.90 & 0.84 & 1.08 & 1.05 & 1.22 & 1.56 & 1.86 \\
\hline$q$ & 2.97 & 1.83 & 3.32 & - & - & - & 17.03 & 11.38 & 1.43 \\
\hline or & 37.87 & 38.08 & 36.46 & 41.11 & 36.71 & 35.61 & 22.02 & 24.09 & 22.88 \\
\hline$a b$ & 50.25 & 50.76 & 50.32 & 48.36 & 54.59 & 53.71 & 40.88 & 56.68 & 64.56 \\
\hline an & 2.85 & 3.60 & 3.66 & 5.60 & 1.34 & 1.69 & 10.94 & - & 5.42 \\
\hline ne & - & - & - & 2.38 & 3.33 & 1.99 & - & - & - \\
\hline $\mathrm{Di}$ & - & - & - & - & 1.21 & 2.75 & 1.69 & 3.58 & 0.12 \\
\hline $\mathrm{Hy}$ & 1.34 & 1.15 & 1.35 & - & - & - & 4.82 & - & 1.31 \\
\hline $\mathrm{Ol}$ & - & - & - & 0.55 & - & 1.44 & - & - & - \\
\hline $\mathrm{mt}$ & 0.96 & 0.16 & 0.81 & 0.31 & 0.31 & 2.11 & 1.46 & 2.39 & 1.85 \\
\hline il & 0.94 & 1.10 & 0.95 & 0.52 & 0.89 & 0.51 & 0.76 & 0.47 & 0.70 \\
\hline $\mathrm{hm}$ & 0.89 & 1.04 & 1.31 & - & 0.94 & - & - & 0.85 & 1.41 \\
\hline $\mathrm{C}$ & 1.63 & 1.96 & 1.55 & 0.95 & - & - & - & - & - \\
\hline ap & 0.27 & 0.31 & 0.24 & 0.20 & 0.66 & 0.18 & 0.38 & 0.04 & 0.31 \\
\hline $\mathrm{ac}$ & - & - & - & - & - & - & - & 0.49 & - \\
\hline $\mathrm{Rb}(\mathrm{ppm})$ & 48 & 60 & 44 & 250 & & 300 & & 107 & \\
\hline $\mathrm{Ba}$ & 90 & 96 & 78 & 160 & & & & 368 & \\
\hline $\mathrm{Sr}$ & 60 & 50 & 60 & 170 & & & 280 & 51 & \\
\hline Co & 11 & 12 & 14 & & & & & & \\
\hline $\mathrm{Cr}$ & $<10$ & $<10$ & $<10$ & & & & & & \\
\hline $\mathrm{Ni}$ & 10 & 10 & 10 & & & 3 & & 5 & \\
\hline V & 50 & 50 & 50 & 10 & & & & & \\
\hline $\mathrm{K} / \mathrm{Rb}$ & 1115 & 900 & 1170 & 235 & & 170 & & 314 & \\
\hline
\end{tabular}

Note: Columns 4, 5 after Baker et al., 1964; Column 6 after Le Maitre, 1962; Column 7 after Bauer et al., 1973; Column 8 after Baker et al., 1974; Column 9 after Macdonald and Katsura, table 6, 1964.

${ }^{\mathrm{a} D S D P}$ samples numbers; Column 1, 359-4-2, $60 \mathrm{~cm}$; Column 2, 359-4-2, $142 \mathrm{~cm}$; Column 3, 359-5-1, $141 \mathrm{~cm}$.

The occurrence of an ash-flow tuff in a deep-ocean environment is very unusual. Only one other ash flow was recovered during the Deep Sea Drilling Project and that is from a relatively shallow depth, about 360 meters, on the Lord Howe Rise in the Tasman Sea (van der Lingen, 1973). On the other hand, ash-flow tuffs are present on several oceanic islands in the Atlantic, such as the Azores (Ridley et al., 1974), Fernando de
Noronha (Baker, 1973), and Ascension (Baker, 1973), and silicic ash and pumice are present as thin beds in all ocean basins.

Whether the tuff was emplaced subaqueously or subaerially is not easily determined. As discussed by Fiske and Matsuda (1964) and Fiske (1969), graded bedding, where pumice lapilli are concentrated near the top of the flow, may be indicative of subaqueous 
TABLE 2

Average Compositions of Feldspar Phenocrysts, Groundmass Laths, and Microlites (Columns 1, 2, 3, Respectively) in Trachy tic Tuff and in Volcanic Ash

(Columns 4, 5, 6; Oldest to Youngest, Respectively) from the Walvis Seamount Province, Eastern South Atlantic Ocean. Compositions are Averages of 50 Point Analyses (in wt \%)

\begin{tabular}{|c|c|c|c|c|c|c|}
\hline & 1 & 2 & 3 & $\begin{array}{c}4 \\
(3-4,67 \mathrm{~cm})\end{array}$ & $\begin{array}{c}5 \\
(3-4,25 \mathrm{~cm})\end{array}$ & $\begin{array}{c}6 \\
(3-3,120 \mathrm{~cm})\end{array}$ \\
\hline $\mathrm{SiO}_{2}$ & 65.3 & 65.6 & 66.8 & 68.5 & 68.5 & 69.0 \\
\hline $\mathrm{Al}_{2} \mathrm{O}_{3}$ & 19.5 & 19.5 & 19.2 & 19.0 & 18.6 & 18.6 \\
\hline $\mathrm{FeO}$ & 0.18 & 0.20 & 0.37 & 0.18 & 0.21 & 0.42 \\
\hline $\mathrm{MgO}$ & $<0.10$ & $<0.10$ & $<0.10$ & $<0.01$ & $<0.01$ & $<0.01$ \\
\hline $\mathrm{CaO}$ & 0.89 & 0.66 & 0.68 & 0.27 & 0.14 & 0.01 \\
\hline $\mathrm{Na}_{2} \mathrm{O}$ & 6.1 & 6.6 & 7.1 & 6.4 & 6.3 & 6.3 \\
\hline $\mathrm{K}_{2} \mathrm{O}$ & 7.2 & 6.5 & 5.6 & 6.5 & 6.6 & 6.5 \\
\hline Total & 99.17 & 99.06 & 99.75 & 100.85 & 100.35 & 100.83 \\
\hline \multicolumn{7}{|c|}{ Number of Ions on the Basis of $32(0)$} \\
\hline $\mathrm{Si}$ & 11.827 & 11.854 & 11.940 & 12.085 & 12.143 & 12.166 \\
\hline $\mathrm{Al}$ & 4.162 & 4.153 & 4.044 & 3.951 & 3.886 & 3.865 \\
\hline $\mathrm{Fe}$ & 0.027 & 0.030 & 0.005 & 0.027 & 0.031 & 0.062 \\
\hline $\mathrm{Ca}$ & 0.173 & 0.128 & 0.130 & 0.051 & 0.027 & - \\
\hline $\mathrm{Na}$ & 2.142 & 2.312 & 2.460 & 2.189 & 2.165 & 2.154 \\
\hline K & 1.663 & 1.498 & 1.277 & 1.463 & 1.492 & 1.462 \\
\hline $\mathrm{Z}$ & 15.989 & 16.007 & 15.984 & 16.036 & 16.029 & 16.031 \\
\hline $\mathrm{X}$ & 4.005 & 3.968 & 3.922 & 3.730 & 3.715 & 3.678 \\
\hline Sum & 19.994 & 19.975 & 19.906 & 19.766 & 19.744 & 19.709 \\
\hline \multicolumn{7}{|c|}{ Weight Percent End Members } \\
\hline An & 4.5 & 3.4 & 3.5 & 1.4 & 0.8 & 0.0 \\
\hline Or & 43.1 & 39.3 & 34.2 & 40.9 & 41.9 & 41.9 \\
\hline $\mathrm{Ab}$ & 52.4 & 57.3 & 62.3 & 57.7 & 57.3 & 58.1 \\
\hline
\end{tabular}

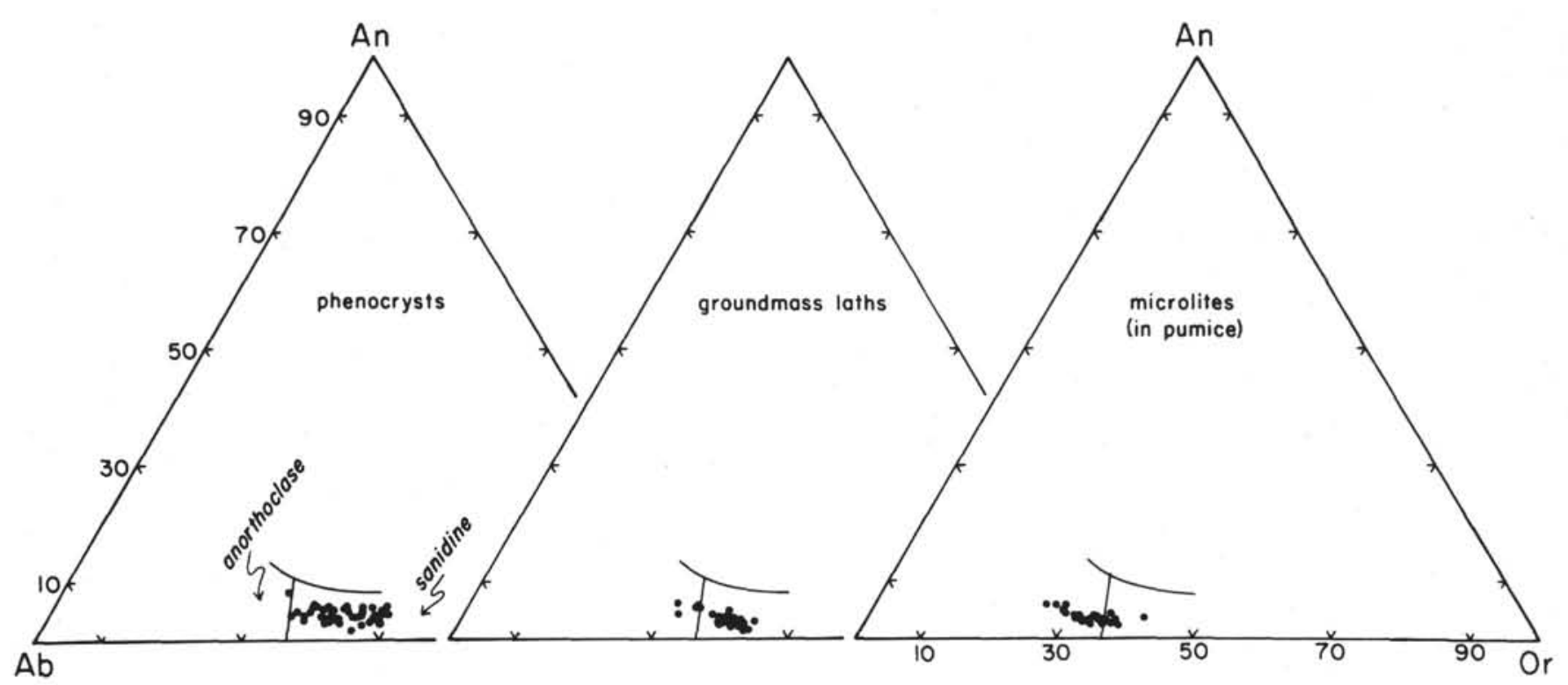

Figure 8. Ternary feldspar diagrams for the different grain sizes of feldspar in the Walvis trachytic ash-flow tuff. Each point analysis is in terms of weight percent end members anorthite $\left(\mathrm{An} ; \mathrm{CaAl}_{2} \mathrm{Si}_{2} \mathrm{O}_{8}\right)$, albite $\left(\mathrm{Ab}, \mathrm{NaAlSi}_{3} \mathrm{O}_{8}\right)$, and orthoclase $\left(\mathrm{Or}, \mathrm{KAlSi}_{3} \mathrm{O}_{8}\right)$. Solid lines mark field boundaries for anorthoclase and sanidine. 
TABLE 3

Average Compositions of

Clinopyroxene and Biotite in

Trachy tic Tuff (Columns 1, 2)

and Volcanic Ash (3-4, 25; Column 3)

from the Walvis Seamount Province,

Eastern South Atlantic Ocean.

Compositions are Averages of 20

Spot Analyses (in wt \%).

\begin{tabular}{|c|c|c|c|}
\hline & 1 & 2 & 3 \\
\hline $\mathrm{SiO}_{2}$ & 51.8 & 37.3 & 47.8 \\
\hline $\mathrm{TiO}_{2}$ & 0.61 & 6.9 & 0.53 \\
\hline $\mathrm{Al}_{2} \mathrm{O}_{3}$ & 1.70 & 14.0 & 0.50 \\
\hline $\mathrm{Cr}_{2} \mathrm{O}_{3}$ & $<0.01$ & $<0.01$ & $<0.01$ \\
\hline $\mathrm{FeO}$ & 10.9 & 19.1 & 30.1 \\
\hline $\mathrm{MnO}$ & 0.69 & 0.31 & 1.20 \\
\hline $\mathrm{MgO}$ & 12.1 & 11.5 & 0.10 \\
\hline $\mathrm{CaO}$ & 20.7 & 0.03 & 18.6 \\
\hline $\mathrm{Na}_{2} \mathrm{O}$ & 0.59 & 0.89 & 0.50 \\
\hline $\mathrm{K}_{2} \mathrm{O}$ & 0.08 & 8.5 & 0.06 \\
\hline Total & 99.17 & 98.53 & 99.39 \\
\hline
\end{tabular}

Number of Ions on the Basis of $6(0)$ for pyroxene; $23^{\mathrm{a}}(0)$ for biotite

$\begin{array}{llll}\mathrm{Si} & 1.966 & 5.742 & 1.991 \\ \mathrm{Al}^{\mathrm{iv}} & 0.034 & 2.258 & 0.009 \\ \mathrm{Al}^{\mathrm{vi}} & 0.042 & 0.282 & 0.016 \\ \mathrm{Ti} & 0.017 & 0.799 & 0.017 \\ \mathrm{Fe} & 0.346 & 2.458 & 1.048 \\ \mathrm{Mn} & 0.022 & 0.040 & 0.042 \\ \mathrm{Mg} & 0.685 & 2.638 & 0.006 \\ \mathrm{Ca} & 0.842 & 0.005 & 0.830 \\ \mathrm{Na} & 0.043 & 0.266 & 0.040 \\ \mathrm{~K} & 0.004 & 1.669 & 0.003 \\ \mathrm{Z} & 2.000 & 8.000 & 2.000 \\ \mathrm{X} & 2.001 & 8.157 & 2.002 \\ \mathrm{Sum} & 4.001 & 16.157 & 4.002\end{array}$

Molecular End Members

\begin{tabular}{lrr} 
Fs & 18.5 & 55.6 \\
En & 36.6 & 0.3 \\
Wo & 44.9 & 44.1 \\
\hline
\end{tabular}

${ }^{a}$ Not $24(0)$, because $\mathrm{H}_{2} \mathrm{O}$ was not determined.

pyroclastic flow. Other features that may suggest a subaqueous depositional environment are reworking of material and the presence of shell and sediment clasts. The absence of these features in the 3.3 meters of core suggests that the tuff represents a subaerial deposit (it should be pointed out, however, that examination of no more than the available 3.3 meters may have precluded detection of graded bedding that may after all be observed if a substantially longer core were available). The relative freshness of the rocks further suggests that is was submerged as a coherent unit rather than having formed from the underwater compaction of individual pyroclastic particles; hyaloclastites, underwater basaltic eruptions, are characteristically altered to clay minerals (e.g., Bonatti, 1967; Melson and Thompson, 1973).
The relief at Site 359 (Figure 2) and the composition and texture of the trachyte (Table 1) indicate a submerged volcanic center capped by a magmatically differentiated rock type. In analogy to nearby Tristan da Cunha and Gough, which are composed of differentiated volcanic suites ranging from basalt to trachyte, deeper drilling of the seamount would probably reveal rocks more mafic in composition, such as trachybasalts and alkalic olivine basalts. The crosssection of the seamount should be viewed in perspective with no vertical exaggeration (as there is in Figure 2), which in reality is a broad, gently sloped volcano, much like a shield volcano. This is characteristic of most seamounts (Menard, 1964), and from the dimensions of the seamounts for the Walvis province $(20$ to $60 \mathrm{~km}$ summit-diameters; Connary, 1972), this is also typical of that entire seamount province.

The sea-floor spreading hypothesis suggests that volcanic islands formed on or near the crest of a midocean ridge and migrated laterally away from the axis (Wilson, 1963). Oceanic crust, on which the islands lie, was also formed at the ridge, solidified, migrated, and cooled by conduction as part of the lithosphere. With continued migration of crust (including overlying islands) the lithosphere increased in depth relative to its ridge-source due to thermal contraction (Sclater et al., 1971). Therefore, volcanic islands generated at a ridge crest should eventually become submerged as they migrate from their source, although continued addition of mantle material via volcanism at a particular center may postpone the submergence of an island.

TABLE 4

Average Compositions of Magnetite (mt) and Ilmenite (ilm) in Trachytic Tuff (Columns 1, 2) and Volcanic Ash (3-4, 67; Columns 3, 4) from the Walvis Seamount Province, Eastern South Atlantic Ocean. Compositions are Averages of $\mathbf{3 0}$ Spot Analyses (in wt \%)

\begin{tabular}{lclccc}
\hline & $\begin{array}{c}1 \\
\mathrm{mt}\end{array}$ & \multicolumn{1}{c}{ (Range) } & $\begin{array}{c}2 \\
\mathrm{ilm}\end{array}$ & $\begin{array}{c}3 \\
\mathrm{mt}\end{array}$ & $\begin{array}{c}4 \\
\text { ilm }\end{array}$ \\
\hline $\mathrm{SiO}_{2}$ & 1.3 & $(1.1-1.4)$ & 0.90 & 0.51 & 0.42 \\
$\mathrm{TiO}_{2}$ & 9.0 & $(6.0-14.5)$ & 47.4 & 24.9 & 47.4 \\
$\mathrm{Al}_{2} \mathrm{O}_{3}$ & 1.7 & $(1.3-2.0)$ & 1.3 & 1.4 & 0.81 \\
$\mathrm{Cr}_{2} \mathrm{O}_{3}$ & 0.01 & & $<0.01$ & 0.03 & $<0.01$ \\
$\mathrm{~V}_{2} \mathrm{O}_{3}$ & $<0.01$ & & $<0.01$ & $<0.01$ & $<0.01$ \\
$\mathrm{FeO}$ & 77.1 & $(71.0-80.9)$ & 44.1 & 69.1 & 45.8 \\
$\mathrm{MnO}$ & 2.5 & $(2.3-3.1)$ & 2.2 & 1.5 & 1.5 \\
$\mathrm{MgO}$ & 0.74 & $(0.45-0.80)$ & 2.2 & 0.02 & 0.01 \\
$\mathrm{CaO}$ & 0.01 & $(0.06-0.19)$ & 0.08 & 0.01 & 0.05 \\
$\mathrm{ZnO}$ & 0.30 & $(0.11-0.51)$ & 0.11 & 0.13 & 0.04 \\
$\mathrm{Sum}$ & 92.75 & & 98.29 & 97.60 & 96.03 \\
$\mathrm{Recalculated}$ & & & & & \\
$\mathrm{FeO}^{\mathrm{a} O}$ & 34.3 & & 37.4 & 52.2 & 41.3 \\
$\mathrm{Fe}_{2} \mathrm{O}_{3}$ & 47.5 & & 7.5 & 18.8 & 5.0 \\
$\mathrm{Total}$ & 97.5 & & 99.1 & 99.5 & 96.5 \\
Usp (mol\%) & 22.4 & & - & 71.9 & - \\
$\mathrm{Hem}$ & - & & 8.3 & - & 5.2 \\
\hline
\end{tabular}

${ }^{a}$ After Carmichael (1967). 
TABLE 5

Average Compositions of Glass Composing Ash in Layers Overlying the Walvis Ash-Flow Tuff, Eastern South Atlantic Ocean. Ash Layers are About 3.6, 4.0, and 4.6 Meters Above the Tuff (Columns 1, 2, 3, Respectively) (in wt \%)

\begin{tabular}{|c|c|c|c|}
\hline & $\begin{array}{c}1 \\
(3-4,67 \mathrm{~cm})\end{array}$ & $\begin{array}{c}2 \\
(3-4,25 \mathrm{~cm})\end{array}$ & $\begin{array}{c}3 \\
(3-3,120 \mathrm{~cm})\end{array}$ \\
\hline $\mathrm{SiO}_{2}$ & 69.1 & 68.2 & 69.3 \\
\hline $\mathrm{TiO}_{2}$ & 0.25 & 0.22 & 0.23 \\
\hline $\mathrm{Al}_{2} \mathrm{O}_{3}$ & 12.1 & 11.6 & 10.9 \\
\hline $\mathrm{FeO}$ & 3.8 & 3.8 & 3.9 \\
\hline $\mathrm{MnO}$ & 0.12 & 0.09 & 0.08 \\
\hline $\mathrm{MgO}$ & $<0.01$ & $<0.01$ & $<0.01$ \\
\hline $\mathrm{CaO}$ & 0.52 & 0.39 & 0.22 \\
\hline $\mathrm{Na}_{2} \mathrm{O}$ & 3.4 & 3.6 & 3.5 \\
\hline $\mathrm{K}_{2} \mathrm{O}$ & 4.8 & 4.9 & 4.5 \\
\hline $\mathrm{P}_{2} \mathrm{O}_{5}$ & 0.03 & 0.01 & 0.01 \\
\hline Total & $94.12^{\mathrm{a}}$ & $92.81^{\mathrm{a}}$ & $92.64^{\mathrm{a}}$ \\
\hline $\mathrm{Na}_{2} \mathrm{O} / \mathrm{K}_{2} \mathrm{O}$ & 0.71 & 0.74 & 0.78 \\
\hline \multicolumn{3}{|c|}{ Molecular norms } & \\
\hline$q$ & 26.79 & 25.04 & 28.62 \\
\hline or & 30.58 & 31.59 & 29.17 \\
\hline$a b$ & 32.92 & 35.27 & 34.48 \\
\hline an & 2.57 & 1.12 & 0.82 \\
\hline wo & 0.00 & 0.40 & 0.15 \\
\hline fs & 0.00 & 0.40 & 0.15 \\
\hline hy-fs & 6.18 & 5.85 & 6.26 \\
\hline il & 0.38 & 0.33 & 0.35 \\
\hline c & 0.52 & 0.00 & 0.00 \\
\hline ap & 0.07 & 0.00 & 0.00 \\
\hline
\end{tabular}

${ }^{a}$ Low totals are probably due to presence of constituents not detectable by the electron microprobe (e.g., $\mathrm{H}_{2} \mathrm{O}$ ).

In view of this model and the location of Site 359 (about $1000 \mathrm{~km}$ from the MAR and just beyond magnetic anomaly 21 ), and considering a spreading rate for the South Atlantic of $2.0 \mathrm{~cm} / \mathrm{yr}$ and the magnetic anomaly time-scale (both in Larson and Pitman, 1972), oceanic crust at Site 359 should be at least 50 m.y. old. But if a volcano was generated at the MAR 50 m.y. ago and completed a differentiation cycle of basalt to trachyte, the age of the last (or near-last) erupted volcanic material would be less than $50 \mathrm{~m} . \mathrm{y}$. The age for the differentiated and young volcanic material on the Site 359 seamount of $40.1 \pm 1$ m.y. is consistent with this hypothesis.

The seamount may have been generated at the MAR at the same hot spot as Tristan da Cunha, differentiated from basalt to trachyte, and migrated northeastward until it was submerged to a depth of about 1750 meters. Assuming a $2 \mathrm{~cm} / \mathrm{yr}$ spreading rate for the South Atlantic, the base of the seamount was at least $200 \mathrm{~km}$ from the MAR when the trachytic tuff was emplaced 40 m.y. ago. Also, the sediments and fossils recovered from directly above the trachyte indicate that about 40 m.y. ago the trachyte was submerged up to 1000 meters in an open-marine environment (Boersma, this volume). Three models for the history of the seamount are therefore possible: (1) The ash-flow tuff is a subaerial deposit from the top of a shield volcano. Shortly after its emplacement (within thousands of years), the summit of the volcano collapsed to a depth of about 1000 meters below sea level. That a shield volcano can collapse to such a great degree is indicated by some Hawaiian volcano calderas (Macdonald, 1972, p. 300). Shallow-water fossils coexisting with openmarine fossils in the overlying sediments (Boersma, this volume) may be material that was mixed in from a shallow-water source, such as a caldera wall, although no such feature is apparent from the seismic profile (Figure 2). (2) The ash-flow tuff is a subaerial deposit from the top of a shield volcano. Although the overlying sediments and fossils are essentially the same age (40 m.y.), the error of 1 m.y. on the K-Ar age of the trachyte and the semiquantitative estimate of paleontological age must be considered. That is, there may actually have been enough time (e.g., 1 m.y. or slightly more) after the ash-flow eruption for normal oceanic-crust subsidence to submerge the volcano 1000 meters below sea level. (3) The ash-flow represents a subaqueous eruption that occurred in an open-marine environment, up to 1000 meters below sea level.

Because petrographic evidence is more agreeable with the trachyte being subaerial, and because subsidence of 1000 meters in such a relatively short time interval is unlikely, model 1 is preferred. In any model, if the trachyte was indeed 1000 meters below sea level 40 m.y. ago, as based on paleontology, a subsequent subsidence of only about 750 meters (the ash flow was cored at about a $1750 \mathrm{~m}$ depth) during $40 \mathrm{~m} . \mathrm{y}$. is not in agreement with the oceanic-crust subsidence curves of Sclater et al. (1971); their data predict about 1400 meters of subsidence during the period $40 \mathrm{~m} . \mathrm{y}$. ago to present. This discrepancy is difficult to reconcile.

The composition of the glass composing the ash layers in the sediments overlying the trachytic tuff indicates that intermediate and possibly silicic volcanic activity, explosive in character, persisted in that general region slightly later than 40 m.y. ago. Alkalic feldspar with and in the ash that is similar in composition to feldspar in the trachytic tuff (Table 2), suggests similar compositional sources for each layer. On the other hand, volcanic sources for the ash differ from the Walvis seamount trachyte by being highly fractionated with respect to $\mathrm{Fe}$ (high $\mathrm{FeO}$ content in glass; hedenbergite).

Investigators during recent years have noticed that volcanic islands of the South Atlantic located farthest from the Mid-Atlantic Ridge are, in general, more $\mathrm{SiO}_{2}$-undersaturated and alkalic than those closer to the MAR (e.g., Baker, 1973). Accordingly, Baker (1973) classified the volcanic island provinces into three compositional (and geographic) groups, namely mildly alkalic, moderately alkalic, and strongly alkalic. Compositionally, the trachyte of Site 359 corresponds to the moderately alkalic Tristan da Cunha and Gough volcanic provinces (Table 1). Geographically, the moderately alkalic Tristan da Cunha and Gough islands are about 400 and $600 \mathrm{~km}$ away from the MAR, respectively. On the basis of location, the Site 359 seamount (about $1000 \mathrm{~km}$ east of the MAR) is more 
compatible with the strongly alkalic group (normally more than $800 \mathrm{~km}$ away from the MAR; Baker, 1973). But volcanism ceased about $40 \mathrm{~m} . y$. ago when the seamount (volcano) was at least $200 \mathrm{~km}$ from the MAR (assuming a constant $2 \mathrm{~cm} / \mathrm{yr}$ migration), and the trachyte is therefore compatible with the moderately alkalic rocks of that region.

Wilson (1965) and Morgan (1971, 1972) proposed that the Walvis ridge originated by the oceanic crust migrating northeastward over a "hot spot" on the MAR. That is, the Walvis Ridge represents a semicontinuous chain of volcanos, where each volcano represents a point that occupied a position above a fixed spot of igneous activity on the spreading ridge. In contrast, Le Pichon and Hayes (1971) and Francheteau and Le Pichon (1972) promoted an origin relating the Walvis Ridge to major fracture zones associated with rifting of the South Atlantic Ocean. Whether or not the Walvis Ridge is a semicontinuous chain of volcanos cannot actually be determined from Site 359 because of its location at the southwest extremity. But Site 359 does perhaps support the "hot spot" origin by showing that Eocene volcanic centers are in fact present directly up to the southwest portion of the ridge proper, and therefore, older submerged volcanic islands could possibly continue northeastward to form a crystalline basement for the ridge.

In summary, drilling at Site 359 revealed the following about the Walvis seamount province:

1) The seamount cored represents a submerged volcanic center that probably completed a differentiation sequence of basalt to trachyte.

2) Compositionally, the trachyte on top of the seamount resembles volcanic material on the nearby islands of Tristan da Cunha and Gough (moderately alkalic).

3) The seamount probably originated at the MAR about 50 m.y. ago, based on crustal spreading rates of about $2 \mathrm{~cm} / \mathrm{yr}$. A K-Ar age of feldspar in the trachyte indicates that it was emplaced 40 m.y. ago. However, explosive volcanic activity of intermediate composition persisted in the region of Site 359 through late Eocene, as indicated by ash deposits in sediments above the seamount.

4) The ash flow was probably deposited subaerially and was shortly followed by collapse of the volcano summit so that the trachyte submerged to an open marine environment.

\section{ACKNOWLEDGMENT}

This work was supported in part by the National Aeronautics and Space Administration, Grants NGL 32-004-063 and NGL 32-004-064 (K. Keil, Principal Investigator).

\section{REFERENCES}

Baker, P.E., 1973. Islands of the South Atlantic. In Nairn, A.E., and Stehli, F.G. (Eds.), The Ocean basins and margins, v. 1: New York (Plenum Press), p. 493.

Baker, P.E., Buckley, F., and Holland, J.G., 1974. Petrology and geochemistry of Easter Island: Contrib. Mineral. Petrol., v. 44, p. 85.

Baker, P.E., Gass, I.G., Harris, P.G., and Le Maitre, R.W., 1964. The volcanological report of the Royal Society expedition to Tristan da Cunha 1962: Phil. Trans. Roy. Soc. London, Ser. A, v. 256, p. 439.

Bauer, G.R., Fodor, R.V., Husler, J.W., and Keil, K., 1973. Contributions to the mineral chemistry of Hawaiian rocks III. Composition and mineralogy of a new rhyodacite occurrence in Oahu, Hawaii: Contrib. Mineral. Petrol., v. 40 , p. 183.

Bonatti, E., 1967. Mechanisms of deep-sea volcanism in the South Pacific. In Abelson, P. (Ed.), Researches in geochemistry, v. 2: New York (John Wiley), p. 453.

Buddington, A.F. and Lindsley, D.H., 1964. Iron-titanium oxide minerals and synthetic equivalents: J. Petrol., v. 5, p. 310 .

Carmichael, I.S.E., 1967. The iron-titanium oxides of salic volcanic rocks and their associated ferromagnesian silicates: Contrib. Mineral. Petrol., v. 13, p. 36.

Connary, S.D., 1972. Investigations of Walvis ridge and environs: PhD dissertation, Columbia University, New York.

Fiske, R.S., 1969. Recognition and significance of pumice in marine pyroclastic rocks: Geol. Soc. Am. Bull., v. 80, p. 1.

Fiske, R.S. and Matsuda, T., 1964. Submarine equivalents of ash flows in the Tokiwa Formation, Japan: Am. J. Sci., v. 262, p. 76 .

Fodor, R.V., Keil, K. and Bunch, T.E., 1975. Contributions to the mineral chemistry of Hawaiian rocks IV. Pyroxenes in rocks from Haleakala and West Maui volcanoes, Maui, Hawaii: Contrib. Mineral. Petrol., v. 50, p. 173.

Francheteau, J. and Le Pichon, X., 1972. Marginal fracture zones as structural framework of continental margins in South Atlantic Ocean: Am. Assoc. Petrol. Geol. Bull., v. 56, p. 991 .

Hekinian, R., 1972. Volcanics from the Walvis ridge: Nature, Phys. Sci. v. 239, p. 91.

Larson, R.L. and Pitman, W.C., 1972. Worldwide correlation of Mesozoic magnetic anomalies, and its implications: Geol. Soc. Am. Bull., v. 83, p. 3645 .

Le Maitre, R.W., 1962. Petrology of volcanic rocks, Gough Island, South Atlantic: Geol. Soc. Am. Bull., v. 73, p. 1309.

Le Pichon, X. and Hayes, D.E., 1971. Marginal offsets, fracture zones and the early opening of the South Atlantic: J. Geophys. Res., v. 76, p. 6283.

Macdonald, G.A., 1972. Volcanoes: Englewood Cliffs, N.J., (Prentice Hall).

Macdonald, G.A. and Katsura, T., 1964. Chemical composition of Hawaiian lavas: Jr. Petrol., v. 5, p. 82.

Melson, W.G. and Thompson, G., 1973. Glassy abyssal basalts, Atlantic sea floor near St. Paul's rocks: Petrography and composition of secondary clay minerals: Geol. Soc. Am. Bull., v. 84, p. 703.

Menard, M.W., 1964. Marine geology of the Pacific: New York (McGraw-Hill).

Morgan, W.J., 1971. Convection plumes in the lower mantle: Nature, v. 230, p. 42.

1972. Plate motions and deep mantle convection: Geol. Soc. Am. Mem., v. 132, p. 7.

Pitman, W.C., Larson, R.L., and Herron, E.M., 1975. Magnetic lineations of the oceans: Geol. Soc. Am. Map.

Ridley, W.I., 1970. The petrology of Los Conadas volcanoes, Tenerife, Canary Islands: Contrib. Mineral. Petrol., v. 26, p. 124.

Ridley, W.I., Watkins, N.D., and MacFarlane, D.J., 1974. The ocean islands: Azores. In Nairn, . and Stehli, . (Eds.) The ocean basins and margins, New York (Plenum Press), p. 445. 
Sclater, J.G., Anderson, R.N., and Bell, M.L., 1971. Elevation of ridges and evolution of the Central eastern Pacific: Jr. Geophys. Res., v. 76, p. 7888.

Tuttle, O.F. and Bowen, N.L., 1958. Origin of granite in the light of experimental studies in the sustem $\mathrm{NaAlSi}_{3} \mathrm{O}_{8}$ $\mathrm{KAISi}_{3} \mathrm{O}_{8}-\mathrm{SiO}_{2}-\mathrm{H}_{2} \mathrm{O}$. Geol. Soc. Am. Mem., v. 74.

van der Lingen, G.J., 1973. The Lord Howe rise rhyolites. In Burns, R.E., Andrews, J.E., et al., Initial Reports of the
Deep Sea Drilling Project, Volume 21: Washington (U.S. Government Printing Office), p. 523.

Wilson, J.T., 1963. Evidence from islands on the spreading of ocean floors: Nature, v. 197, p. 536.

Wilson, J.T., 1965. Convection currents and continental drift XIII. Evidence from ocean islands suggesting movement in the earth: Phil. Trans. Roy. Soc. London, v. 258, p. 19. 